\title{
A novel Ayurvedic medical fumigant powder Bhootastgandha and its effect in Combating Airborne pathogens - A detailed pharmacological activity review
}

\author{
Review Article
}

\section{Sethu R $\mathbf{R}^{*}$, Sara Monsy Oommen²}

\section{Assistant Professor, Department of Dravyagunavijnana, Government Ayurveda College, Tripnithura.}

2. Professor, Department of Dravyagunavijnana, Government Ayurveda College, Kannur, Kerala.

\begin{abstract}
Infectious diseases are becoming popular with every passing day and viral infections among them are the cause for a large number of fatalities since last two decades. All the factors including the lifestyle pave the way to reduced immunity making the human population susceptible to infections. Management of diseases is not only important; prevention of further diseases should also be of prime concern. Infectious diseases that spread through a variety of mediums like air, water etc. requires preventive measures that controls the spread of the microorganisms and keep the preventive aspect intact. Ayurveda treatment has succeeded in achieving both treatment aspect as well as preventative aspect of diseases. Dhoopana Karma is an important modality \& primitive method of sterilization which can be used in preventive and curative aspect. The yoga "Bhootastagandha" is taken from the Ayurvedic compilation Sarvaroga Chikitsa Ratnam". Learning about the practical application of the formulation, the formulation is mentioned among a group of formulations used as fumigating agents. The formulation consists of a group of 8 drugs and all the drugs on pharmacological screening is found to possess Antimicrobial, Antibacterial, Antiviral, Antifungal properties among other pharmacological actions. The details about the pharmacological activity of the drugs are collected from various research articles published. This review article mainly focuses on the phytochemical properties of the ingredient drugs as per Ayurveda classics and the utility of the formulation as an effective fumigant keeping in mind the Antimicrobial, Anti-viral, Anti -Fungal and Anti- Bacterial action of the plants.
\end{abstract}

Key Words: Ayurveda, Fumigant, Bhootastagandha, Anti-Bacterial, Antimicrobial.

\section{Introduction}

The plant kingdom has always amused us with its incredible diversity and vibrant applications in our day-to-day life as well as in medicine. Ayurveda focusing mainly on natural herbs has proved that natural herbs are a source pool for various pharmacological agents that play a pivot role in various health problems. Traditional medicine researchers and practitioners claim that medicinal plants are more effective to treat infectious diseases compared to synthetic antibiotics(1).The usage of traditional herbal medicine has always been preferred and appreciated due to its easy availability and cost-effective applications. The main active principles present in the plant are the secondary metabolites and the important pharmacological actions of these plants are attributed to these secondary metabolites(2).

In the current global situation, there is an increased incidence of infectious diseases among which important are air borne infectious diseases like SARS,

\section{* Corresponding Author:}

\section{Sethu R}

Assistant Professor,

Department of Dravyagunavijnana,

Government Ayurveda College,

Tripnithura. India

Email Id: forever.lords.feet@gmail.com
Covid -19. Scientists and research faculty worldwide are focused on developing control measures to prevent and combat infection. It is necessary to identify the method of transfer of microorganism from one being to another which is ultimately necessary to develop appropriate measures to combat further spread and infection. Among all the mediums through which the microorganisms propagate, air is one of the most dangerous mediums as the microorganisms once dispersed into the air get suspended in the air for varying amount of time depending upon its density and can easily enter the human body through inhalation of the air. The minute droplets containing the microorganisms are dispersed into the air on coughing and sneezing. Depending upon the density of the droplets, they travel far or retain near in the atmosphere

To prevent and combat the growth, transport and propagation of microorganisms and their transport and propagations through various mediums, various measures need to be adopted accordingly. Such measures to prevent the growth and propagation are generally included under the disinfection and sterilization methods. Sterilization is of different types and choosing the apt sterilization method depends upon mainly three factors: target, purpose, the type of medium used or administered and area of application. It can either be through heat, radiation, fumes etc. Among various effective sterilization methods employed to combat the growth and spread of microbial agents and 
to control surgical site infections, fumigation, or sterilization with the help of medicated fumes are commonly used. Fumigation acts mainly by preventing the growth and propagation of microorganisms or microbial agents thereby ensuring biological cleanliness and a completely sterile atmosphere.

According to Ayurveda, when it comes to various diseases apart from tridosha being the root cause, sometimes microorganisms that are airborne and infectious also tend to be the reason. Throughout Ayurveda it can be seen that various herbal remedies are mentioned as fumigants to combat such infectious organisms and thereby prevent the diseases. When we look throughout the classics it is evident that, Ayurveda classics have mentioned multiple sterilization methods like water purification, homa, yagna, dhoopana etc to ensure a sterile atmosphere and inorder to prevent the spread of micro-organisms. Among the various methods mentioned comes the Dhoopana karma where the drugs or drug components of herbo-mineral or animal origin are used for fumigation(3).

The term fumigation is derived from the Latin word "Fumus" means smoke and "ago" meaning drive away. The fumigation process carried out using fine powder of selected dry drugs with the intention of sanitization is called Dhoopana. Ayurveda Samhitas has cited many dhoopana yogas in different contexts. Aparajitha churna is a significant example. It is a widely used standard fumigative mentioned in infectious fever treatment in Chakradatta. Recently conducted research regarding Aparajitha churna reveal its antimicrobial property and its ability to sterilize the environment. There are so many similar unexplored fumigative formulations in Ayurveda.

The use and application of sterilization and disinfection is mainly applicable in cases of industrial research and health facilities which includes a lot of enclosed environments.In such cases, chemicals like formaldehyde whose antimicrobial and disinfecting action has already been proved,however it is evident that these chemicals aare toxic to human beings. So, the challenge is always there to find better alternatives, so that the target organisms could be eliminated without adversely affecting human beings.

"Bhootastagandha" is a Dhoopana yoga taken from the compilation book "Sarvaroga Chikitsa Ratnam" by Aanakellil S Gopalapilla, mentioned in the bheshaja kalpa of the text. The yoga is a combination of 8 drugs that are basically fragrant in nature and contains various volatile components and essential oils. Even though the yoga is typically indicated by the author in Apasamara Chikitsa, it can also be incorporated for Dhoopana Karma.

\section{Materials and Methods}

Relevant section of all Ayurveda classics including the Samhitas and Nighantus were referred to collect the Ayurvedic literature relating to the formulation and the ingredients of the yoga Bhootastagandha.

We have gone through the phytochemical and pharmacological profiles from the research articles published. Articles having importance on antimicrobial property with respect to its phytochemical constituents are included under the review. Relevant pharmacological evaluations conducted with various parts used and phytochemical constituents of the individual drugs of the formulation was collected through Internet and other contemporary sources.

\section{Description in Ayurvedic texts about Dhoopana and Bhutagna/ Rakshogna action of drugs}

In Ayurveda, the term Dhoopana is mentioned in various contexts, Dhoopana is mentioned as one among the Sodhana procedures which is used to alleviate and expel the vitiated kapha from the body.

Acharya Susruta in Susruta Samhita has also explained the importance and the necessity for dhoopana karma with rakshoghna dravya.(4), while going through the classical text it is evident that Acharya has mentioned many dhoopana formulations throughout the text for various types of microorganisms. Apart from Acharya Susruta, Acharya vagbhata, Charaka,Kashyapa, also mentions about dhoopana karma and various yogas mentioned for the same.

Acharya Susruta has explained Rakshavidhana in Shasti Upakrama. Raksha Vidhana is the $60^{\text {th }}$ upakrama which is classified in sodhana and ropana chikitsa. Acharya has advised to administer Dhoopana for Vranita ( Wounded Patients) and they should also be protected by mantras, yama, niyama etc. To prevent the attack of micro-organisms, Acharya has mainly mentioned "Saptaopakrama" where he has mentioned 7 upakrama's mentioning shodhana prior to ropana. From this classification and arrangement Acharya Susruta emphasizes on the importance of sodhana or the sterilization aspect before the ropana(5)

Acharya Charaka in Charaka Samhita, Chikitsasthana $25^{\text {th }}$ chapter has explained Dhoopana karma for prevention of vrana(6). In Ashtanga Sangraha there is description of Dhoopana in Rakshavidhi. Also, there is advice of Dhoopana to the Sutikaagara with the help of Dravyas mentioned in Vrana Chikitsa(7).Acharya Kashyapa has given separate Dhoomakalpaadhyaya for Dhoopana, aim of this Adhyaya is to keep Sutika and newborn healthy. He has described different Dhoopas and advised in Garbhaavastha, Dhoopana of bed, clothe, chair and whole Sutikagruha. It shows that Dhoopana is helpful in disinfecting the environment of a particular area(8).

All Acharya including the Brihatrayi's have in detail mentioned about the Rakshoghna and the Bhootagna karma under various contexts and have also mentioned various drugs with rakshoghna / bhootagna, krimighna properties which would refer to the antimicrobial and antiviral action of the drugs. The usage of such drugs can be exclusively seen in the portions dealing with treatment of Vrina, Bala, Sootika.Acharya Kashyapa has dedicated an entire chapter in Kashyapa Samhita as Dhoopa kalpa where he mentioned various formulations of dhoopana useful in the prevention and curing of pediatric diseases. Acharya Vagbhata in Astanga sangrahaUtharasthana -38th chapter and Astanga hridaya Utharatantra 25th 
chapter has also explained in detail about the rakshoghna and bhootagna karmas, Acharya has also included the drugs used for dhoopana.(9)
The classical indication of Dhoopana Karma in epidemics suggests exploring its role in managing the outbreaks of many new emerging infectious diseases.

Table 1: Indication of Dhoopana Karma According to Various Acharyas (10)

\begin{tabular}{|c|c|c|c|c|}
\hline Acharya Charaka & Acharya Susruta & Acharya Vagbhata & Kashyapa & Bhela Samhita \\
\hline Jwara Jirna Jwara & Sutika & Post-operative & Balaroga & Aparasaga \\
\hline Unmada & Vrina & Garbhasanga & Griharoga & Arsa \\
\hline Apasmara & Aparapatana & Visamajwara & Sisu paricharya \\
\hline Kustha & Garbhasanga & Arsa & \\
\hline Arsa & Karnaroga & Balagraha, Visa & \\
\hline Vrina & Visamajwara & Pediatic ward & \\
\hline Pradara & Yoniroga & Bhutagraha & \\
\hline Aparapatana & Newborn & Unmada & \\
\hline Kumaragara & Postoperative cases & Urdhwajatru vikara & \\
\hline
\end{tabular}

Table 2: Ingredients with Botanical name of the drugs and their family

\begin{tabular}{|c|c|c|c|}
\hline Drug & Scientific name & Family & Part Used \\
\hline Karpasa & Gossypium herbaceum Linn & Malvaceae & Seed \\
\hline Lasuna & Allium sativum Linn. & Liliaceae & Skin \\
\hline Guggulu & Commiphora mukul ( Hook.ex Stocks) Engl & Burseraceae & Resin \\
\hline Putidaru & Sterculia foetida Linn. & Sterculiaceae & Heartwood \\
\hline Jatamansi & Nardostachys jatamansi DC & Valerianaceae & Rhizome \\
\hline Kustha & Saussurea lappa C B Clarke & Apocynaceae & Root \\
\hline Aguru & Aquilaria agallochaRoxb. & Thymeleaceae & Heartwood \\
\hline Ushira & Vetiveria zizaniodes (Linn.) & Poaceae & Root \\
\hline
\end{tabular}

\section{Pharmacological properties of the Drugs}

Pharmacological properties of each individual drugs in the formulation were collected from all the authentic texts and also opinions on the pharmacological properties by the Nighantu was also collected. On detailed understanding of the Pharmacological properties of the drugs it can be observed that Katu (Pungent) and Tikta(Bitter) was predominant and most common rasa.
Among the drugs mentioned, Putidaru (Sterculia foetida Linn) is an Extra -pharmacoepial drug and the pharmacological properties and the actions of the drug was not quite evident in the classics. The Action and the pharmacological property of the drug were collected from the studies conducted on the drug.

While examining in detail about the opinion of different Acharya's on each drug, there are mentioning about the indication of the drug for conditions like Krimi, Kustha, Jantu, Bhutabadha etc.(11)

Table 3: Pharmacological Property of the Essential/ Volatile Chemical constituents

\begin{tabular}{|c|c|c|}
\hline Drug & Essential oils/ Volatile Phytochemicals & Pharmacological Action \\
\hline Jatamasi & $\begin{array}{l}\text { Patchoul (24.3\%), } \alpha \text { - Bulnesene (13.8\%), Isovaleric Acid (12.9\%), } \alpha \text {-Guaiene } \\
(8.7 \%) \text {, 3-Methylvaleric Acid (8.4\%) }\end{array}$ & $\begin{array}{l}\text { Insecticidal, Antimicrobial } \\
\text { ( Fumigant)(12) }\end{array}$ \\
\hline Kustha & $\begin{array}{l}\text { Steroidal Alkaloids - } 68 \text { (Conessine), Flavonoids, Triterpenoids, Phenolic Acids, } \\
\text { Tannin, Resin, Coumarins, Saponins, Ergostenol }\end{array}$ & $\begin{array}{l}\text { Larvicidal } \\
\text { Antimicrobial(13) } \\
\text { Antifeedant, Antibacterial(14) }\end{array}$ \\
\hline Karpasa & $\begin{array}{l}\text { Gossypetin, Gossypol, Quercetin, Betaine, Choline, Salicylic Acid, Saturated } \\
\text { Fatty Acids Viz Oleic, Palmitic And Stearic Acids. }\end{array}$ & $\begin{array}{l}\text { Antibacterial Activity } \\
\text { Insecticidal(15) } \\
\text { Antimicrobial(16) } \\
\text { Antiviral(17) }\end{array}$ \\
\hline Putidaru & $\begin{array}{l}\text { Anthocyanins, Coumarins, Flavonoids And Their Glycosides, Phenolic Acids, } \\
\text { Phenylpropanoids, Sesquiterpenes, Triterpenes, Sterols and Fatty Acids And } \\
\text { Alcohols Tannins, 2-Deoxysugars, Leucoanthocyanin, And Benzopyrone } \\
\text { Nucleus. }\end{array}$ & $\begin{array}{l}\text { Insecticidal } \\
\text { Antimicrobial Action(18) }\end{array}$ \\
\hline Lasuna & $\begin{array}{l}33 \text { Sulphur Compounds, Several Enzymes, } 17 \text { Amino Acids, Selenium } 22 \\
\text { Sulphur-Containing Phytoconstituents Such As Alliin, Allicin, Ajoenes, } \\
\text { Vinyldithiins, And Flavonoids Such As Quercetin. }\end{array}$ & Antibacterial(19), Antiviral(20) \\
\hline Agaru & $\begin{array}{l}\text { Alkaloid,Anthroquinone, Fixed Oil and Fats, Glycoside, Tannin, Triterpenoids } \\
\text { Saponins, Steroids, Flavonoids And Phenol Compounds }\end{array}$ & Antimicrobial(21) \\
\hline Ushira & $\begin{array}{l}\text { Vetiverol, Vetivone, Khusimone, Khusimol, Vetivene, Khositone, Terpenes, } \\
\text { Benzoic Acid, Tripene-4-Ol, ß-Humulene, Epizizianal, Vetivenyl Vetivenate, Iso } \\
\text { Khusimol, ß-Vetivone, Vetivazulene }\end{array}$ & Antimicrobial $(22,23)$ \\
\hline
\end{tabular}


Guggulu Contains Gum (32\%), Essential Oil (1.45\%), Sterols (Guggulsterols I

To VI, B-Sitosterol, Cholesterol, Z- And E-Guggulsterone), Sugars (Sucrose,

Guggulu Fructose), Amino Acids, A-Camphorene, Cembrene, Allylcembrol, Flavonoids Antimicrobial(24)

(Quercetin and Its Glycosides), Ellagic Acid, Myricyl Alcohol, Aliphatic Tetrols.

Monoterpenoids, Sesquiterpenoids, Triterpenoids, Diterpenoids, Flavanoids

\section{Discussion}

Infectious diseases are caused by the invasion of microorganisms into the human body through various pathways. Among all the pathways through which infectious microorganisms enter into the body, air is one of the most important mediums as the microorganisms that are suspended into the air can easily enter into the body through the upper respiratory tract. The invasion and attack of these microorganisms can be prevented by using proper sterilization and sanitary measures. Among the sanitization methods which was very popularly used in the ancient times as well as being used in the current times is Fumigation. Fumigation acts as an effective method of disinfection and sanitization and are of different types based on the ingredient used. Ayurvedic classics have mentioned numerous formulations for fumigation where a group of drugs of specific action are selected and powdered and fumigated. This enables the drug to exert their antiviral, antimicrobial actions thereby destroying the capability of the microorganism to cause harm.

The Bhootaghnal Rakshoghna property exhibited by the formulation and the mechanism of associated pharmacological activity exhibited by the drugs can be mainly understood by the detailed understanding of the phytochemical constituents and their activity. On observing the phytochemical composition of each drug, it was found that all drugs in the formulation contains volatile essential oils, fatty acids, methanol and ethanolic compounds all of which might contribute to the antimicrobial, insecticidal, antibacterial, and antifungal properties.

Among the phytochemical constituents present in the drugs, alkaloids, polyphenols, polysaccharides, proteins, saponins, terpenes, coumarins, quinones, steroids etc. exhibit significant antiviral properties. Alkaloids present in the drug mainly exert their action by blocking the binding of the virus with the host organism, inhibiting viral growth, and making the condition unsuitable for the multiplication and propagation of the viruses. Another phytochemical component, polysaccharide present in the drug inhibit the replication of virus and its binding to the host cell.flavanoids inhibit RNA synthesis, Terpenes inhibits replication of Virus, lecithin inhibit viral penetration into the cell. Similarly different pharmacological actions can be seen attributed to various phytochemical constituents present. Phytochemicals like Flavanoids: Luteolin, apigenin, quercetin, Kaempferol, myricetrin Interfere with the activation of NRP 3 inflammasome(25). The review on the drugs shows the effectiveness of each drug in combating microorganisms.

The Drug Karpasa mainly contains polyphenolic compound Gossypol, and contains saturated fatty acids viz oleic acid, palmitic acid and stearic acid. These oleic and palmitic acid have proven antibacterial activity(26).

In case of Lasuna (Garlic), it contains about 22 Sulphur compounds and has been used as an effective fumigant since ancient time. In folklore practice, garlic seeds are dehusked, the husk is burned, and the fumes are exposed to various plants including vegetables and herbs to prevent the attack of microbes and worms. Classical references also show the use of garlic in Jantu Roga (27). While going through the phytochemical components of garlic, it contains essential oils diallyl disulphide and diallyl trisulphide that have significant fumigant action(28).Allicin, a primary Sulphur compound present in garlic has proved to be a potential fumigant to control insects(29). An SEM analysis conducted showed reduced number of bacterial growth on garlic husk fumigated surface samples. The result of this study proves the effectiveness of ayurvedic fumigants in combating air-borne bacteria and in surface disinfection.(30).

The Drug "Guggulu” is most common ingredient in various single drug usage as well as compound formulations found in the classical texts. The synonyms like Devadhupa, Mahadhupa, Dhupika itself reflects the fumigant property of the drug. Guggulu dhoopana is indicated in various diseases like agantuja jwara, sawasa, vrina, bhootapratishedha and karnaroga. Sesquiterpene fractions present in the drug contain furanodiene -6-one and methoxy furanoguaia-9eene-8one shows better antifungal and antibacterial activity against standard strains of pathologic species. $(31,32,33)$.

Similarly antimicrobial and insecticidal actions have been reported in the drug Putidaru due to the Prescence of volatile sesquiterpenes and sterculia $\operatorname{gum}(34)$.

The drug Jatamansi is given the synonym Bhutaghni which substantiates its antimicrobial and disinfectant property and can be seen as a common dhoopana dravya used as a single drug as well as in compound formulations. Acharya Susruta has indicated jatamansi for snaihika dhuma, and also as a fumigant for warding off bhuta in Bhutapratishedha in kumaragara(35).

Acharya Charaka and Acharya Vagbhata have advocated the use of the drug "Kustha" in the treatment of Infective fever, where the twig of the drug is burned, and the fumes are exposed to the diseased(36).The insecticidal action of the drug can be related to the presence of alkaloids and essential oils present in the drug.

Another important fumigant ingredient in the formulation is Agaru, the drug has synonyms like Dhuparha, Dhoopayopgika which substantiates its 
fumigative action. According to the classics, the drug possesses Krimighna action and is indicated in karnaroga and sterilization of post-operative rooms. The principal chemical constituents that are responsible for the fumigant action is the Sesquiterpenoids and phenylethylchromone derivatives (37).

Other key ingredients in the formulation are Putidaru and Ushira, major chemical constituents of the drug include terpenes and terpenoids, flavonoids, sterols, fatty acids etc which are responsible for their significant insecticidal and antimicrobial action upon fumigation. Ushira is a widely used fumigant due to its fragrance and aroma during combustion.

The reviewed pharmacological actions of each individual drugs substantiate and supports its usage of the formulation for Antiviral, Antimicrobial, AntiBacterial intentions while selecting the drug as an effective fumigant.

\section{References}

1. Mathur A, Singh R, Yousuf S, Bhardwaj A, Verma SK, Babu P, et al. Antifungal activity of some plant extracts against clinical pathogens. Adv Appl Sci Res 2011; 2:260-4.

2. Lai PK, Roy J. Antimicrobial and chemo preventive properties of herbs and spices. Curr Med Chem 2004; 11:1451-60.

3. Bailey and Love. Short Practice of Surgery. Oxford University Press Publication, New York, 23rd Ed., 2000. 123

4. Bailey and Love. Short Practice of Surgery. Oxford University Press Publication, New York, 23rd Ed., 2000. 120

5. Kaviraj Ambikadutta Shastri, Susruta Samhita part I, Choukamba surbharti prakashan, Varanasi, Sutrasthana, 17/22;96

6. Kashinatha Shastri. Charaka Samhita Part-2. Chokhamba Bharati Acadamy, Varanasi, 4th Ed., 2001.714.

7. Atridevgupta. Ashtanga Sangra Part-1.Choukhamba Bharati Acadamy, Varanasi, 2nd Ed., 1999. 131.

8. Shrisatyapala Bhishagacharya. Kashyaapa Samhita. Choukhamba Sanskrut Sansthana, Varanasi, 1st Ed. Reprint 2009. 171-173

9. Sreyas Madan gadag, Dr R H Amilkanthwar, Concept of Sterilization in Ayurveda : A Review, World Journal of Pharmacuetical and medical research, 2019,5(5), 51-53

10. Manita ahlawat, Reetu sharma, S K Mandal, dhoopana karma in ayurveda texts: a review, International Ayurvedic medical journal, 2019,7(5);770-776

11. Sharma P V, Classical uses of Medicinal Plants, Choukambha Viswabharti, 2014, page 124-127

12. Liu, Xin \& Zhou, Ligang \& Liu, Zhi long. (2013). Identification of insecticidal constituents from the essential oil of Valeriana jatamansi Jones against Liposcelis bostrychophila Badonnel. E-Journal of Chemistry. 2013. 853912. 10.1155/2013/853912.

13. Thappa, R. Tikku, K. \& Saxena, Bhaskar, Vaid, Raj $\&$ Bhutani, Kamlesh.. Conessine as a larval growth inhibitor, sterilant, and antifeedant from Holarrhena antidysenterica Wall. International Journal of Tropical Insect Science. 10. 10.1017/ S1742758400010304.

14. Michał Krzyzowski et.al, The short-chain fatty acids as potential protective agents against Callosobruchus maculatus infestation, Journal of Stored Products Research 86 2020/101570

15. Sultana Arshiya et al: Gossypium herbaceum Linn: An Ethnopharmacological Review, JPSI 1 (5), Sept - Oct 2012, 1-5

16. Chaturvedi A, Singh S and Nag TN: Antimicrobial activity of flavonoids from in vitro tissue culture and seeds of Gossypium species. Romanian Biotechnological Letters 2010; 15(1):4959-4963.

17. Antiviral activities of gossypol and its derivatives against herpes simplex virus type II, https://doi.org/ 10.1016/0031-6989 (86)90023-8

18. Pierangeli G. Vital et.al, Antimicrobial activity, cytotoxicity and phytochemical screening of FicussepticaBurm and Sterculiafoetida L. leaf extracts, Journal of Medicinal Plants Research Vol. 4(1), pp. 58-63

19. P Saravanan et.al, Antibacterial activity of Allium sativum Linn. on pathogenic bacterial strains, Global vetirinaria, 4(5): $519-522 ; 2010$

20. Mehrbod, Parvaneh \& Amini, Elham \& Kheiri, Masoumeh. (2009). Antiviral activity of garlic extract on Influenza virus. Iranian J Virol. 3. 19-23. 10.21859/isv.3.1.19.

21. Manasi Dash, Jayanta Kumar Patra, Prasanna Priyadarshini Panda, Phytochemical and antimicrobial screening of extracts of Aquilaria agallocha Roxb, African Journal of Biotechnology Vol. 7 (20), pp. 3531-3534

22. David A, Wang F, Sun X, et al. Chemical Composition, Antioxidant, and Antimicrobial Activities of Vetiveria zizanioides (L.) Nash Essential Oil Extracted by Carbon Dioxide Expanded Ethanol. Molecules. 2019; 24(10):1897. Published 2019 May 17. doi:10.3390/ molecules 24101897

23. (Devprakash et al., Antimicrobial activity of alcoholic and aqueous extracts of Vetiveria zizanioides, Journal of Pharmacy Research Vol.4.Issue 5. May 2011, Journal of Pharmacy Research 2011, 4(5), 1343-1344.

24. Sarup P, Bala S, Kamboj S. Pharmacology and Phytochemistry of Oleo-Gum Resin of Commiphora wightii (Guggulu). Scientifica (Cairo). 2015 ; $2015: 138039$. doi:10.1155/2015/138039

25. Mrs. Remya Dev Renjith, Dr. Minnie Sankar, Scope Of Phytochemicals In The Management Of Covid-19, Pharmaceutical Resonance 2020 Vol. 3 Issue 1, $26-29$

26. Trease and Evans Pharmacognosy, William C Evans, 2009,Edinburgh, Saunders/Elsevier, Pg. 261

27. Sharma P V, Classical uses of Medicinal Plants, Choukambha Viswabharti, 2014, page 124-127 
28. S. Rajendran, V. Sriranjini Plant products as fumigant for stored product insect control, Journal of Stored Products Research 44 (2008) 126-135

29. $\mathrm{Lu} \mathrm{Y}$ et al., Fumigation toxicity of allicin against three stored product pests, Journal of Stored Products Research,2013:55;48-54

30. Bagde, Sushma \& Shukla, Prashant \& Srivastava, Rupesh \& Mondal, Rajesh \& Anupam, Rajaneesh. (2019). Validation of environmental disinfection efficiency of traditional Ayurvedic fumigation practices. Journal of Ayurveda and Integrative Medicine. 10. 10.1016/j.jaim.2019.05.002.

31. Trease and Evans Pharmacognosy, William C Evans, 2009,Edinburgh, Saunders/Elsevier, Pg. 298

32. Goyal P., Chauhan A., Kaushik P. Assessment of Commiphora wightii (Arn.) Bhandari (Guggul) as potential source for antibacterial agent. Journal of Medicine and Medical Sciences. 2010;1(3):7175 .

33. Ishnava K. B., Mahida Y. N., Mohan J. S. S. In vitro assessments of antibacterial potential of Commiphora wightii (Arn.) Bhandari. gum extract. Journal of Pharmacognosy and Phytotherapy. 2010;2(7):91-96.

34. Vital PG et al. antimicrobial activity, cytotoxicity and phytochemical screening of FicussepticaBurm and Sterculiafoetida L. leaf extracts. J Med Plant Res 2010; 4: 58-63.

35. Jha SV, Bhagwat AM, Pandita N . Pharmacognostic and Phytochemical studies on the rhizome of Nardostachys jatamansi DC. Using different extracts. Journal of Pharmacognosy. 2012; 4(33):16-23.

36. Anwar Khalid et.al, antimicrobial activity analysis of extracts of Acacia modesta, Artimisiaabsinthium, Nigella sativa and Saussurealappa against Gram positive and Gram negative microorganisms, African Journal of Biotechnology Vol. 10(22), pp. 4574-4580, 30 May, 2011

37. Miraghaee, Sayyed \& Karimi, Isaac \& Becker, Lora. (2011). Psychobiological assessment of smoke of agarwood (Aquilaria spp.) in male rats. Journal of Applied Biological Sciences. 